Z. WANG, X. WANG, P. WANG, J. ZHAO* (GUANGZHOU MEDICAL UNIVERSITY, NORTHWESTERN POLYTECHNICAL UNIVERSITY, XI'AN, JIANGXI NORMAL UNIVERSITY, NANCHANG, AND NANKAI UNIVERSITY, TIANJIN, P. R. OF CHINA)

Allenone-Mediated Racemization/Epimerization-Free Peptide Bond Formation and Its Application in Peptide Synthesis J. Am. Chem. Soc. 2021, 143, 10374-10381, DOI: 10.1021/jacs.1c04614.

\section{Allenone-Mediated Formation of Peptide Bonds}

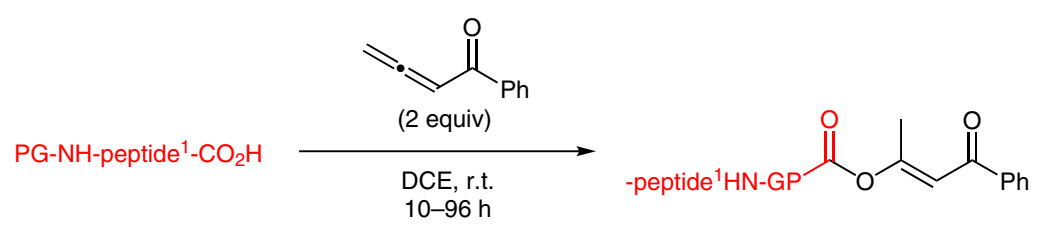

\section{Category}

Peptide Chemistry

\section{Key words}

\section{allenones}

$\alpha$-carbonyl vinyl esters

peptide-bond formation

\section{$\underset{\text { Synfact }}{\text { of ite }}$ Month}

\title{
Selected examples:
}<smiles>CCCCOC(=O)C(COCCC)NC(=O)[C@H](CC(C)C)NC(=O)C(Cc1ccccc1)NC(=O)[C@H](C)NC(F)F</smiles>

$94 \%$ yield in 2 steps, de $>99 \%$<smiles>CCCCOC[C@H](NC(=O)[C@H](Cc1ccc(OC(C)(C)C)cc1)NC(=O)[C@H](Cc1ccccc1)NC(=O)[C@@H](NC(=O)OCc1ccccc1)C(C)C)C(=O)N[C@@H](CC(C)C)C(=O)OCCC</smiles>

$82 \%$ yield in 2 steps, de $>99 \%$<smiles>CCCCOC(=O)CC[C@H](NC(=O)[C@H](C)NC(=O)CNC(=O)C(Cc1ccccc1)NC(=O)OCc1ccccc1)C(=O)N[C@@H](Cc1ccccc1)C(=O)N[C@@H](CC(C)C)C(=O)OCCC</smiles>

$86 \%$ yield in 2 steps, de $>99 \%$<smiles>CCCCOC[C@H](NC(=O)[C@H](COCCC)NC(=O)[C@H](CC(C)C)NC(=O)CNC(=O)[C@H](Cc1ccccc1)NC(=O)OCc1ccccc1)C(=O)N[C@@H](Cc1ccccc1)C(=O)OCCC</smiles>

$90 \%$ yield in 2 steps, de $>99 \%$

Significance: The development of an efficient method for amide bond formation is important in peptide drug discovery. The authors have developed an allenone-mediated peptide synthesis.
Comment: This allenone-mediated amidation reaction affords peptides containing a variety of amino acid residues in high yields without any epimerization. 